Check for updates

Cite this: RSC Adv., 2019, 9, 11369

Received 29th January 2019

Accepted 1st April 2019

DOI: 10.1039/c9ra00778d

rsc.li/rsc-advances

\title{
Modified SiO hierarchical structure materials with improved initial coulombic efficiency for advanced lithium-ion battery anodes $\uparrow$
}

\author{
Lizhao Xie, (D) Hui Liu, Shaoxiong Lin, Xulai Yang, Meizhou Qi, Lili Zhu, Yujing Guo \\ and Guilue Guo*
}

\begin{abstract}
Silicon-based anode materials are indispensable components in developing high energy density lithium-ion batteries, yet their practical application still faces great challenges, such as large volume change during the lithiation and delithiation process that causes the pulverization of silicon particles, and continuous formation and reformation of the solid electrolyte interfaces (SEI) which results in a low initial coulombic efficiency. As an endeavor to address these problems, in this study, $\mathrm{Si} / \mathrm{SiO} / \mathrm{Li}_{2} \mathrm{SiO}_{3} \mathrm{aC}$ structures were prepared via a facile method using $\mathrm{SiO}$, pitch powder and $\mathrm{Li}_{2} \mathrm{CO}_{3} / \mathrm{PVA}$ solution followed by annealing treatment. The $\mathrm{Si} / \mathrm{SiO} / \mathrm{Li}_{2} \mathrm{SiO}_{3} @ \mathrm{CC}$ composite shows a great improvement in lithium storage where a high discharge capacity of $1645.47 \mathrm{~mA} \mathrm{~h} \mathrm{~g}^{-1}$ was delivered with the $1^{\text {st }} \mathrm{C}$.E. of $69.05 \%$ at $100 \mathrm{~mA} \mathrm{~g}^{-1}$. These results indicate that the designed method of integrating prelithiation and carbon coating for $\mathrm{SiO}$ and the as-prepared macro scale $\mathrm{Si} / \mathrm{SiO} / \mathrm{Li}_{2} \mathrm{SiO}_{3} \mathrm{CC}$ structures are practical for implementation in lithium-ion battery technology.
\end{abstract}

\section{Introduction}

During the last five decades, exacerbating air pollution together with the concerns of severe fossil fuel depletion have drawn public awareness of accelerating the electrification of our transportation systems. ${ }^{1,2}$ The ever-increasing demand for electric buses (E-bus) and electric vehicles (EVs) has thus stimulated the development of high performance lithium ion batteries (LIBs). However, graphite, the primary anode material, which has a theoretical capacity of $372.22 \mathrm{~mA} \mathrm{~h} \mathrm{~g}^{-1}$, cannot satisfy the high energy density requirement of the EVs and is not usually considered as an anode material in these types of LIBs, e.g. $300 \mathrm{~W} \mathrm{~h} \mathrm{~kg}^{-1}$ battery packs. ${ }^{3-5}$ Among the various types of candidate anodes proposed for LIBs, Si-based materials have high theoretical capacities, e.g., $\mathrm{Si}$ with a capacity of $4211.52 \mathrm{~mA} \mathrm{~h} \mathrm{~g}^{-1}\left(\mathrm{Li}_{4.4} \mathrm{Si}\right)$ or $3589.28 \mathrm{~mA} \mathrm{~h} \mathrm{~g}^{-1}\left(\mathrm{Li}_{3.75} \mathrm{Si}\right)$ and silicon monoxide (SiO) of $2322.15 \mathrm{~mA} \mathrm{~h} \mathrm{~g}^{-1}$, which have attracted intensive research efforts in both academic and industrial area. ${ }^{6-9}$ However, Si-based materials still suffer from huge volume expansion and pulverization issues, which inevitably lead to the rapid failure of the battery. ${ }^{10-13}$

Hefei Guoxuan High-Tech Power Energy Co., Ltd., Hefei, P. R. China. E-mail: gguooo2@e.ntu.edu.sg

$\dagger$ Electronic supplementary information (ESI) available: The XRD pattern of the solute from the wash supernatant, the morphology of the $\mathrm{Si} / \mathrm{SiO} / \mathrm{Li}_{2} \mathrm{SiO}_{3} @ \mathrm{C}$ composites after acid treatment, charge and discharge profiles of three samples at $50 \mu \mathrm{A}$. The electrochemical performance of BTR material and $\mathrm{Si} / \mathrm{SiO} / \mathrm{Li}_{2} \mathrm{SiO}_{3} @ \mathrm{C}$ composite. See DOI: 10.1039/c9ra00778d
So far, various methods have been proposed and employed to modify Si-based materials in order to improve their lithium storage performance. ${ }^{14,15}$ For example, constructing core/shell structure nanoparticles/nanowires where $\mathrm{Si}$ acts as core materials and $\mathrm{SiO} / \mathrm{SiO}_{2}$ serves as shell layers have been realized through solution methods or physical/chemical vapor deposition. Such one-dimensional core/shell nanostructure allows the delivery of high capacity and maintains high capacity retention. ${ }^{16-18}$ Polymer coating on Si-based materials has also led to significant improvement in specific capacity and cycling performance because of the prevention of Si particles aggregation as well as accommodation of their volume expansion. ${ }^{19-21}$ Fabrication of various Si-based composite materials, e.g. Sicarbon nanotubes, ${ }^{22,23}$ metal fibril mat-supported silicon anode,$^{24}$ etc. is also demonstrated for high performance lithium storage. In addition, surface coating with carbon or metal layer on Si-based materials to avoid direct contact between $\mathrm{Si} / \mathrm{SiO}$ and electrolytes is also proved to be effective in promoting stable solid electrolyte interphase (SEI) and increasing the electric conductivity to maximize the overall electrochemical performance. ${ }^{25-27}$

Compared with the huge volume change of pure Si during lithiation, the volume expansion issue of SiO is less severe than that of $\mathrm{Si}$, thus $\mathrm{SiO}$ is currently more preferable in integrating into EVs batteries anodes. ${ }^{28,29}$ However, SiO encounters several drawbacks. One is the low intrinsic electrical conductivity, which lowers the electrochemical activity; another is the low initial coulombic efficiency $\left(1^{\text {st }}\right.$ C.E. $)$ because the oxygen component in SiO can irreversibly consume some Li during the 
first cycle. ${ }^{30,31}$ These consumed Li need to be compensated so that the $1^{\text {st }}$ C.E. of the anode could be close to those of cathodes before it is widely used. ${ }^{32,33}$ Benefit from the investigation of $\mathrm{Si}$ anodes, great advancement has been achieved in solving the pulverization of SiO. ${ }^{34-36}$ Recently, some research attention is directly paid to solving the low $1^{\text {st }}$ C.E. problem. Their attempts mainly focus on converting the $\mathrm{O}$ atoms in the SiO to a buffer layer like $\mathrm{SiAl}_{0.2} \mathrm{O}^{37}$ or lithium silicates ${ }^{38}$ during materials synthesis stage, but no significant progress has been available. Furthermore, the nanosized LIBs electrode materials provided in these studies is not yet practical for industrial application. It is of extremely urgent and meaningful to develop an effective and efficient method to tackle these issues so as to pave the way for the practical implementation of SiO.

In this work, a novel method was developed to prepare carbon-coated prelithiated micron-sized SiO anode materials for lithium storage, which is displayed in Fig. 1. Hierarchical free-standing $\mathrm{SiO}-\mathrm{Li}_{2} \mathrm{CO}_{3} / \mathrm{PVA}$ sponges were first prepared through solution method, followed by annealing in $\mathrm{N}_{2}$ flow to generate macroscale $\mathrm{Si} / \mathrm{SiO} / \mathrm{Li}_{2} \mathrm{SiO}_{3} @ \mathrm{C}$ hierarchical structures. Such composites combining the advantages of carbon-coating and prelithiation are desirable in lithium storage. When tested as lithium-ion battery anode, a high capacity of $1645.47 \mathrm{~mA} \mathrm{~h} \mathrm{~g}^{-1}$ was obtained with a high $1^{\text {st }}$ C.E. of $69.05 \%$ compared to $12.29 \%$ of the pristine SiO-based anode at $100 \mathrm{~mA} \mathrm{~g}^{-1}$. Rate capability testing shows that when 100, 200, 500,1000 and $2000 \mathrm{~mA} \mathrm{~g}^{-1}$ current densities were applied, the delivered capacities are 748.59, 609.68, 487.13, 311.52 and $197.80 \mathrm{~mA} \mathrm{~h} \mathrm{~g}^{-1}$, respectively.

\section{Methods}

\section{Materials preparation}

In a typical synthesis, $10.0 \mathrm{~g}$ polyvinyl alcohol (average $M_{\mathrm{w}}$ : 31 000, Sigma Aldrich, 99.9\%) were first dissolved in $180 \mathrm{~g} 80^{\circ} \mathrm{C}$ DI water to form a transparent solution through continuous stirring, after which $18.0 \mathrm{~g}$ lithium carbonate $\left(\mathrm{Li}_{2} \mathrm{CO}_{3}\right.$, Sigma
Aldrich, 99.9\%) was added to form the PVA- $\mathrm{Li}_{2} \mathrm{CO}_{3}$ solution. To prepare the $\mathrm{SiO}-\mathrm{Li}_{2} \mathrm{CO}_{3}$-PVA sponge, $2.62 \mathrm{~g}$ silicon monoxide (SiO, Sigma Aldrich, 99.9\%, $D_{50}=5.07 \mu \mathrm{m}$ ) were mixed with $50 \mathrm{~mL}$ PVA- $\mathrm{Li}_{2} \mathrm{CO}_{3}$ solution under stirring for $10 \mathrm{~min}$, then $10 \mathrm{~mL}$ alcohol (Sigma Aldrich, 99.5\%) where $0.8 \mathrm{~g}$ pitch powder was previously dissolved was rapidly dropped into the above mixture solution to form the $\mathrm{SiO}-\mathrm{Li}_{2} \mathrm{CO}_{3}$-Pitch-PVA sponge. The final mole ratio of $\mathrm{SiO}: \mathrm{Li}_{2} \mathrm{CO}_{3}$ in the sponge was adjusted to be $8: 1$. The obtained sponges were then kept in a $100{ }^{\circ} \mathrm{C}$ vacuum oven for 3 hours to evaporate the remained water and alcohol. The dry sponges were then transferred into a tube furnace and annealed at $1000{ }^{\circ} \mathrm{C}$ under nitrogen flow for 6 hours to form the $\mathrm{Si} / \mathrm{SiO} / \mathrm{Li}_{2} \mathrm{SiO}_{3} @ \mathrm{C}$ structures. The $\mathrm{Si} / \mathrm{SiO} / \mathrm{Li}_{2} \mathrm{SiO}_{3} @ \mathrm{C}$ structures were further treated by $2.0 \mathrm{M} \mathrm{HNO}_{3}$ for 60 minutes to remove some of the $\mathrm{Li}_{2} \mathrm{SiO}_{3}$ as well as introduce some pore structures. Carbon-coated $\mathrm{SiO}$ (SiO@C) were also prepared through carbonation of the sponge obtained from a mixture of pristine SiO-PVA solution and ethanol-pitch powder solution.

\section{Physical characterization}

The morphologies of the pristine $\mathrm{SiO}, \mathrm{SiO} @ \mathrm{C}$ and $\mathrm{Si} / \mathrm{SiO} / \mathrm{Li}_{2}-$ $\mathrm{SiO}_{3} @ \mathrm{C}$ were visualized using field-emission electron microscopy (FESEM, FEI, Nova NanoSEM 450 operated at $1 \mathrm{kV}$ ). The phases of these samples were identified using X-ray diffraction (XRD, Rigaku SmartLab $3 \mathrm{~kW}, 40 \mathrm{kV}$ ) with $\mathrm{Cu} \mathrm{K} \alpha$ irradiation.

\section{Electrochemical evaluation}

For the preparation of working electrodes, $80 \mathrm{wt} \%$ active materials, $10 \mathrm{wt} \%$ super $\mathrm{P}$ carbon and $10 \mathrm{wt} \%$ LA133 binder (5 wt $\%$ in $\mathrm{H}_{2} \mathrm{O}$, purchased from Chengdu Indigo Power Sources Co., Ltd) were mixed with DI water and stirred to form a slurry. The black slurry thus obtained was coated on $\mathrm{Cu}$ foil by an automated doctor blade and followed by drying under a vacuum environment at $90{ }^{\circ} \mathrm{C}$ for $12 \mathrm{~h}$ to remove the solvent. The dry electrodes were calendared and the total material loading was $\sim 6 \mathrm{mg} \mathrm{cm}^{-2}$. The electrodes were assembled into CR2016 coin cell in an argon-filled glove box configuration with lithium

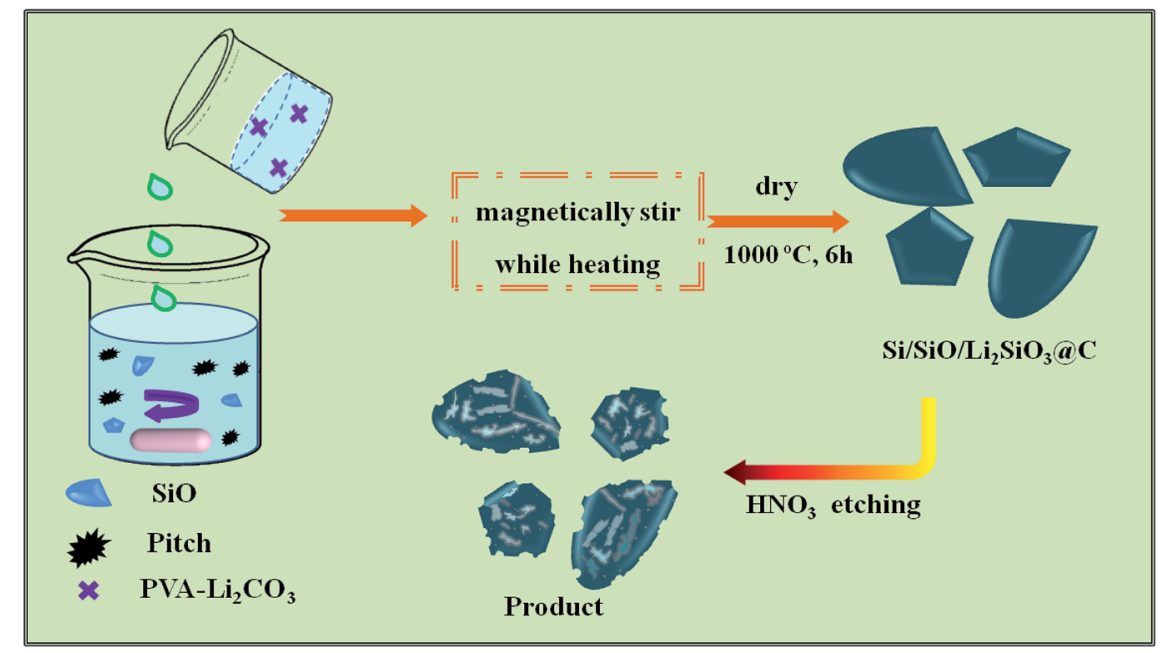

Fig. 1 Schematic synthesis procedures of the $\mathrm{Si} / \mathrm{SiO} / \mathrm{Li}_{2} \mathrm{SiO}_{3} \mathrm{aC}$ composites. 
metal foil as the counter/reference electrode, polypropylene separator (Celgard 2400), and electrolyte solution obtained by dissolving $1 \mathrm{M} \mathrm{LiPF}_{6}$ and $5 \% \mathrm{FEC}$ in a mixture of ethylene carbonate (EC) and dimethyl carbonate (DMC) (EC/DMC, $1: 1$, $\mathrm{v} / \mathrm{v})$. The charge/discharge tests were performed using a NEWARE battery tester in a voltage window of 0.005-1.5 V. Cyclic voltammetry characterizations $(0.005 \mathrm{~V}$ to $\mathrm{OCV})$ were performed using an electrochemical workstation (Solartron analytical equipment, 1287 Electrochemical Interface). EIS measurement was carried out on the same equipment as CV with a frequency ranging from $100 \mathrm{kHz}$ to $0.01 \mathrm{~Hz}$ (1260 Impedance/Gain-Phase Analyzer). Before the EIS tests, the coin cells were fully discharged and then charged to $50 \%$ SOC.

\section{Results and discussion}

Fig. 1 illustrates the synthesis procedure of the $\mathrm{Si} / \mathrm{SiO} / \mathrm{Li}_{2}-$ $\mathrm{SiO}_{3} @ \mathrm{C}$ composites where more details are available in the experiment section.

The XRD patterns of the pristine SiO, carbon coated-SiO ( $\mathrm{SiO} @ \mathrm{C}$ ) and $\mathrm{Si} / \mathrm{SiO} / \mathrm{Li}_{2} \mathrm{SiO}_{3} @ \mathrm{C}$ are displayed in Fig. 2. For the pristine $\mathrm{SiO}$, a broad peak around $20-30^{\circ}$ was observed, corresponding to the amorphous nature of SiO, which has been revealed to be composed of silicon nanocrystals, $\mathrm{SiO}_{2}$ and amorphous $\mathrm{SiO}_{x}(0<x<2)$ interfaces. SiO@C exhibits two peaks, where the broad peak around $20-30^{\circ}$ was $\mathrm{SiO}$ and the peak at $28.5^{\circ}$ belongs to nanosized Si generated from the disproportion of SiO during the carbonization process. Diffraction patterns corresponding to $\mathrm{Li}_{2} \mathrm{SiO}_{3}$ (PDF no. 290828), nano-sized Si (PDF no. 27-1402) and the remained SiO are observed in the XRD profile of $\mathrm{Si} / \mathrm{SiO} / \mathrm{Li}_{2} \mathrm{SiO}_{3} @ \mathrm{C}$, which suggests the successful synthesis of $\mathrm{Si} / \mathrm{SiO} / \mathrm{Li}_{2} \mathrm{SiO}_{3}$ composites.

The morphologies of the SiO, $\mathrm{SiO} @ \mathrm{C}$ and $\mathrm{Si} / \mathrm{SiO} / \mathrm{Li}_{2} \mathrm{SiO}_{3} @ \mathrm{C}$ composites are displayed in Fig. 3. As shown in Fig. 3a, the pristine SiO particles are 1-5 $\mu \mathrm{m}$ in diameter which have irregular shapes and smooth surfaces. The SiO@C shares similar dimensions with the pristine SiO particles while the

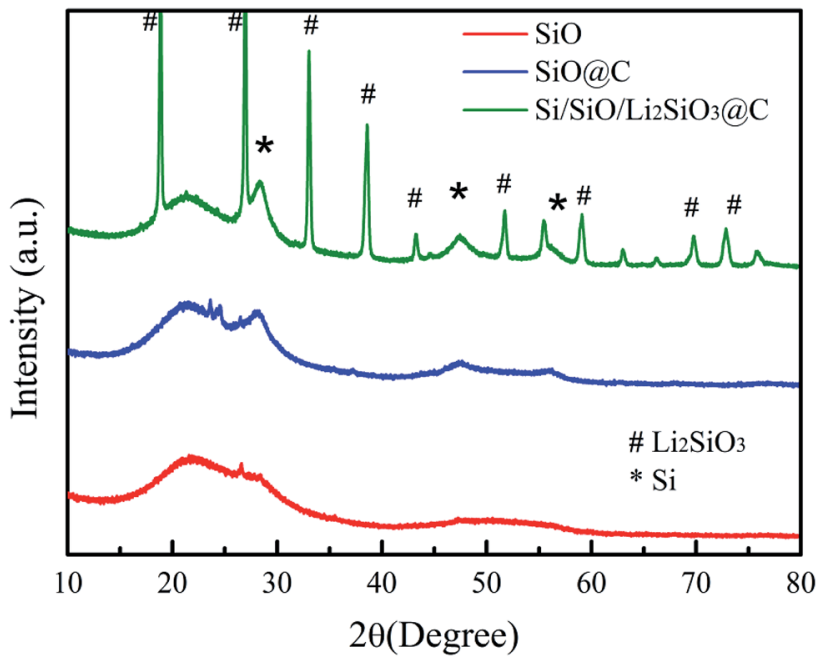

Fig. 2 XRD patterns of $\mathrm{SiO}, \mathrm{SiO} @ \mathrm{C}$ and $\mathrm{Si} / \mathrm{SiO} / \mathrm{Li}_{2} \mathrm{SiO}_{3} \mathrm{CC}$. surfaces of each particle are covered by a layer of carbon derived from the carbonization of PVA and pitch powder as indicated in Fig. 3b. The $\mathrm{Si} / \mathrm{SiO} / \mathrm{Li}_{2} \mathrm{SiO}_{3} @ \mathrm{C}$ composites have the same morphology with the carbon-coated SiO where layers of carbon were found to be coated on the surfaces or intercalated among different particles. After further acid treatment of the $\mathrm{Si} / \mathrm{SiO} /$ $\mathrm{Li}_{2} \mathrm{SiO}_{3}$ @C, pore structures were generated in the composites due to the partial dissolution of the $\mathrm{Li}_{2} \mathrm{SiO}_{3}$ phases. The reaction was revealed to be $\mathrm{Li}_{2} \mathrm{SiO}_{3}+2 \mathrm{HNO}_{3} \rightarrow 2 \mathrm{LiNO}_{3}+\mathrm{H}_{2} \mathrm{SiO}_{3}$, which was confirmed by the XRD pattern of the solute of the supernatant obtained from acid treatment and the material inside was proved to be pure $\mathrm{LiNO}_{3}$ (ESI, Fig. S1†). Higher magnification SEM image (Fig. 3d and S2 in the ESI $\dagger$ ) further visualizes the porous structure of the composites. The surface area (SA) of pristine $\mathrm{SiO}$ and $\mathrm{SiO} @ \mathrm{C}$ are measured to be 2.01 and $3.53 \mathrm{~m}^{2} \mathrm{~g}^{-1}$. Dramatic increase in $\mathrm{SA}$ is observed in the $\mathrm{Si} / \mathrm{SiO} /$ $\mathrm{Li}_{2} \mathrm{SiO}_{3} @ \mathrm{C}$ composites which reaches $14.04 \mathrm{~m}^{2} \mathrm{~g}^{-1}$ due to the introduction of pore structures. Such as-prepared interconnected porous $\mathrm{Si} / \mathrm{SiO} / \mathrm{Li}_{2} \mathrm{SiO}_{3} @ \mathrm{C}$ composites are desirable in high performance lithium storage application where the porous structures provide not only free space for volume expansion accommodation but also efficient channels for $\mathrm{Li}^{+}$ diffusion.

The electrochemical properties of the pristine $\mathrm{SiO}, \mathrm{SiO} @ \mathrm{C}$ and $\mathrm{Si} / \mathrm{SiO} / \mathrm{Li}_{2} \mathrm{SiO}_{3} @ \mathrm{C}$ composites were investigated in half-cell batteries. The $\mathrm{CV}$ responses of the coin-cells using these anode materials are shown in Fig. 4. Different CV responses are observed from the three types of coin cells. For the pristine SiO (Fig. 4a), in the first cycle, the broad peak ranging from $0.2-0.5 \mathrm{~V}$ and the shape peak followed at around $0.05-0.2 \mathrm{~V}$ can be attributed to the conversion and lithiation process corresponding to the lithiation of $\mathrm{Si}$ and irreversible formation of $\mathrm{Li}_{2} \mathrm{SiO}_{3}{ }^{39,40}$ During the anodic scan, peaks at around $0.6 \mathrm{~V}$ correspond to the delithiation of Li-Si alloys. In the following cycles, the lithiation and delithiation peaks all slightly shift to the lower potential, which demonstrates the dominant process is the lithiation and delithiation of $\mathrm{Si}$ as $\mathrm{SiO}$ was converted into $\mathrm{Si}$ and $\mathrm{Li}_{2} \mathrm{SiO}_{3}$ during the first cycle. It is noted that the anodic peak in the $2^{\text {nd }}$ cycle is the strongest, suggesting an activation process and in the $3^{\text {rd }}$ cycle, its amplitude weakens, indicating a stable state is achieved or a possible degradation may have occurred, as pristine $\mathrm{SiO}$ is fragile upon cycling. The $\mathrm{CV}$ profiles of SiO@C are far more complicate compared with that of SiO and are exhibited in Fig. 4b. In the first cathodic scan, a broad peak centered at around $0.65 \mathrm{~V}$ appears which is related to the formation of the solid-electrolyte interface (SEI) layer. In the $2^{\text {nd }}$ and $3^{\text {rd }}$ cycle, this peak shifts to around $1.0 \mathrm{~V}$ and the intensity is weaker. The lithiation peaks below $0.2 \mathrm{~V}$ turn broader and their intensities increase as cycle number increases, which is contrary to that of pristine SiO. These results suggest a different SEI formation mechanism as well as a gradual utilization of SiO after carbon coating. The anodic scan also show a gradual increase of peak intensities upon cycling and the peaks slightly shift to the higher potential. For the $\mathrm{Si} / \mathrm{SiO} / \mathrm{Li}_{2} \mathrm{SiO}_{3} @ \mathrm{C}$, similar CV responses as SiO@C are observed where broader cathodic and anodic peaks compared with SiO@C are centered at around 0.1 and $0.2 \mathrm{~V}$, respectively, as shown in Fig. $4 \mathrm{c}$. 


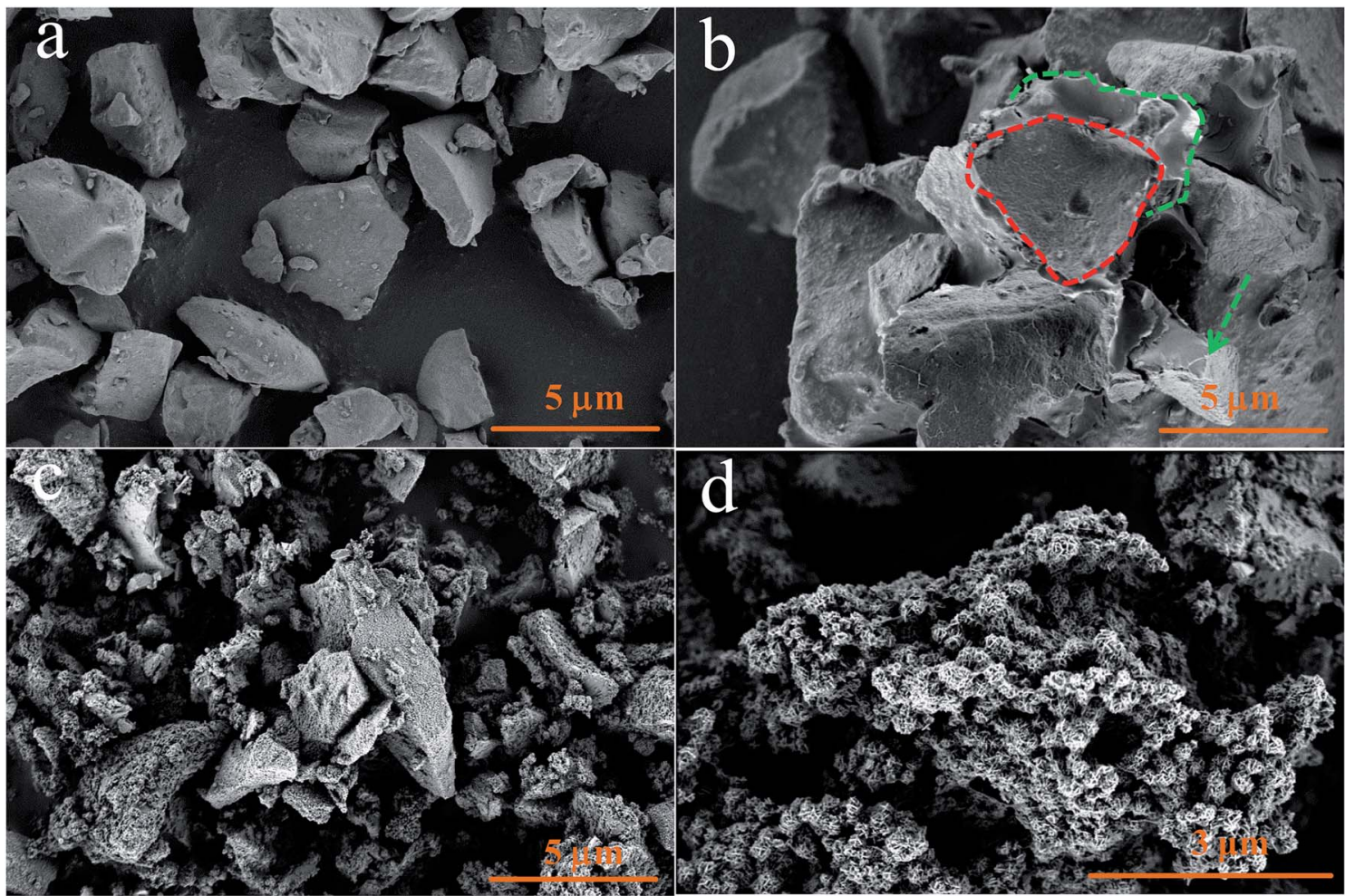

Fig. 3 Morphologies of (a) pristine $\mathrm{SiO}$, (b) carbon-coated $\mathrm{SiO}$, (c and d) $\mathrm{Si} / \mathrm{SiO} / \mathrm{Li}_{2} \mathrm{SiO}_{3} \mathrm{CC}$ composites. Scale bar: (a-c) $5 \mu \mathrm{m}$ and (d) $3 \mu \mathrm{m}$.
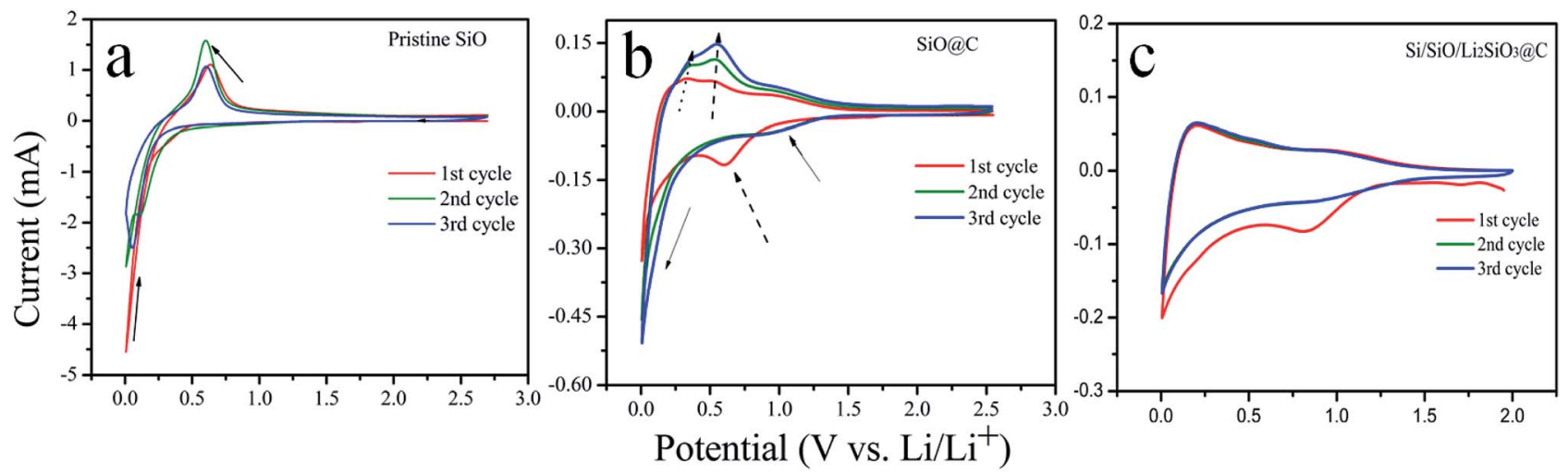

Fig. $4 \mathrm{CV}$ curves of $\mathrm{SiO}, \mathrm{SiO} @ \mathrm{C}$ and $\mathrm{Si} / \mathrm{SiO} / \mathrm{Li}_{2} \mathrm{SiO}_{3} \mathrm{aC}$ at a scan rate of $0.1 \mathrm{mV} \mathrm{s}^{-1}$.

Fig. 5a shows the first charge and discharge curves of the coin-cells using the above mentioned anode materials at a current density of $100 \mathrm{~mA} \mathrm{~g}^{-1}$. The discharge voltage of pristine $\mathrm{SiO}$ is 0.1-0.2 V higher than those of $\mathrm{SiO} @ \mathrm{C}$ and $\mathrm{Si} / \mathrm{SiO} /$ $\mathrm{Li}_{2} \mathrm{SiO}_{3} @ \mathrm{C}$ composites. It may be caused by the differences in reaction kinetics and hindrance where in pristine $\mathrm{SiO}, \mathrm{SiO}$ directly contacted with electrolyte, while in the later two cases, carbon layers surrounded the particles resulting in different SEI structures. Another reason is the disproportion of SiO during the carbonization process in the $\mathrm{SiO} @ \mathrm{C}$ and $\mathrm{Si} / \mathrm{SiO} / \mathrm{Li}_{2} \mathrm{SiO}_{3} @ \mathrm{C}$ composites and the different discharge-charge curves between nano-sized $\mathrm{Si}$ and micron-sized SiO. ${ }^{\mathbf{4 1 , 4 2}}$ The charge and discharge curves of $\mathrm{SiO} @ \mathrm{C}$ and $\mathrm{Si} / \mathrm{SiO} / \mathrm{Li}_{2} \mathrm{SiO}_{3} @ \mathrm{C}$ composites almost overlay with each other except for the end of charge and discharge, which indicates similar conversion and alloying reactions with different degrees of sluggish in kinetics. For the pristine $\mathrm{SiO}$, the initial discharge and charge capacity are 1787.89 and $219.88 \mathrm{~mA} \mathrm{~h} \mathrm{~g}^{-1}$ respectively, in which the $1^{\text {st }}$ C.E. is as low as $12.29 \%$. It is also noted that the delivered capacities rapidly fade for pristine $\mathrm{SiO}$ and at the $5^{\text {th }}$ cycle, dropping to only 95.03 and $89.28 \mathrm{~mA} \mathrm{~h} \mathrm{~g}^{-1}$, which evidently show that pristine SiO is not suitable to be applied in practical battery cells (Fig. 5b). When SiO was coated with 5\% of carbon (SiO@C), the initial discharge and charge capacities increase to 1759.46 and $1021.02 \mathrm{~mA} \mathrm{~h} \mathrm{~g}^{-1}$ with a $1^{\text {st }}$ C.E. of $58.03 \%$, which is a significant improvement compared with that of pristine SiO. The mechanisms under such improvements in specific capacities and $1^{\text {st }}$ C.E. can be attributed to both the enhancement of 

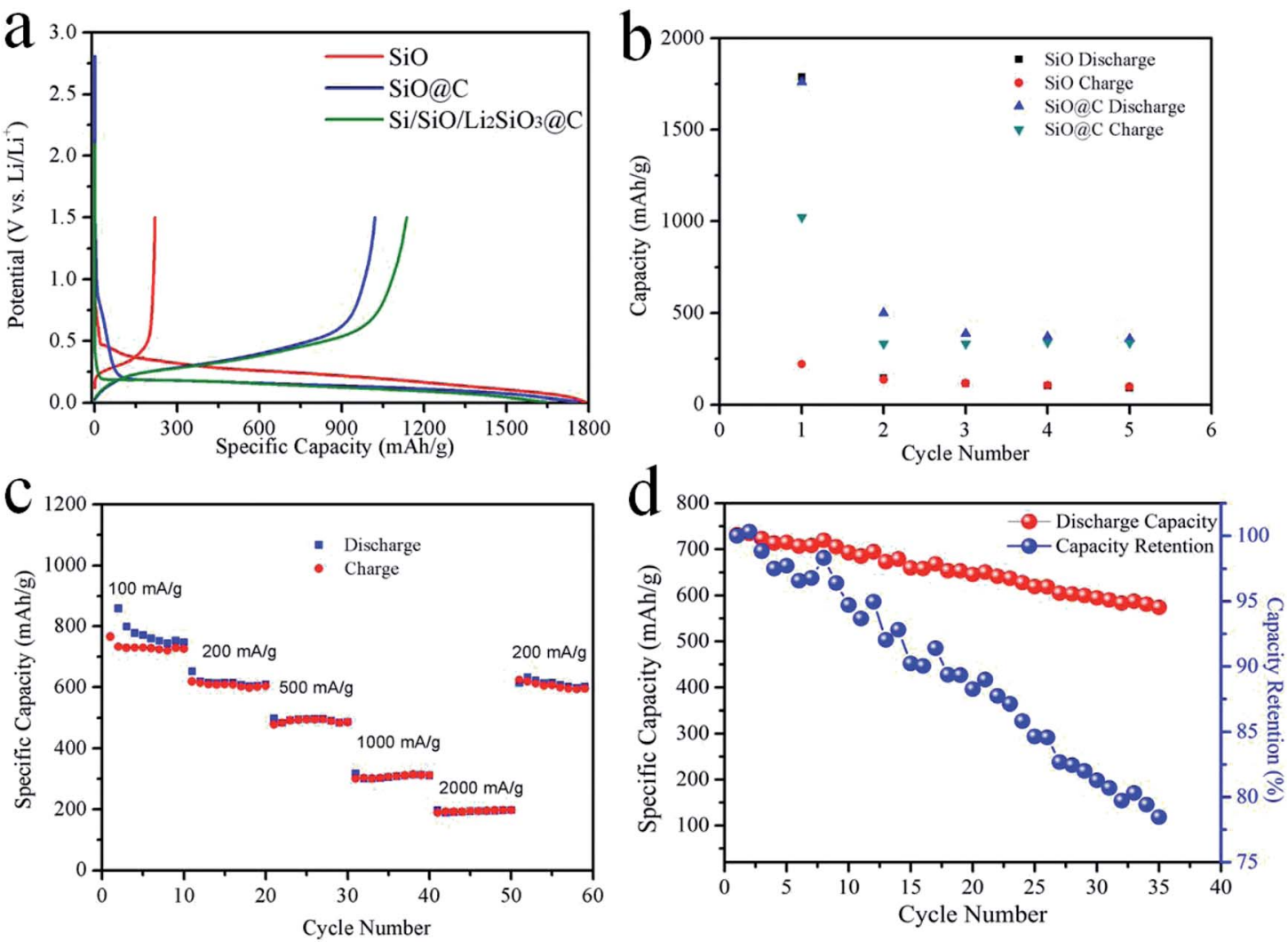

Fig. 5 (a) The charge/discharge voltage profiles of pristine $\mathrm{SiO}$, $\mathrm{SiO} @ \mathrm{C}$ and $\mathrm{Si} / \mathrm{SiO} / \mathrm{Li}_{2} \mathrm{SiO}_{3} \mathrm{aC}$ composites at the $1^{\text {st }} \mathrm{cycle}$, (b) capacities of $\mathrm{SiO}$ and $\mathrm{SiO} @ \mathrm{C}$ in the initial 5 cycles, (c) rate capability and (d) cycle performance of the $\mathrm{Si} / \mathrm{SiO} / \mathrm{Li}_{2} \mathrm{SiO}_{3} \mathrm{aC}$ composites.

electric conductivity and prevention of direct contact of $\mathrm{SiO}$ with the electrolyte to avoid SEI formation on SiO by the introduction of the exterior carbon layer. ${ }^{43}$ Although improved $1^{\text {st }}$ cycle performance was achieved, the delivered capacities at the following cycles behave similarly as the pristine $\mathrm{SiO}$ (Fig. $5 \mathrm{~b}$ ). As some SiO particles underwent huge volume expansion and cracked during discharge, these particles were not recovered during the following delithiation process and the interior lithiation parts were further electronically isolated due to the shrinkage of the delithiation portion, which inevitably exacerbates the capacity fading of these two kinds of materials. The delivered capacities of the $\mathrm{Si} / \mathrm{SiO} / \mathrm{Li}_{2} \mathrm{SiO}_{3} @ \mathrm{C}$ composites in the first cycle are 1645.47 and $1136.18 \mathrm{~mA} \mathrm{~h} \mathrm{~g}^{-1}$, corresponding to a $1^{\text {st }}$ C.E. of $69.05 \%$. The $2^{\text {nd }}$ and $3^{\text {rd }}$ cycle charge capacities are stable at around $800 \mathrm{~mA} \mathrm{~h} \mathrm{~g}{ }^{-1}$. The rate performance of the $\mathrm{Si} /$ $\mathrm{SiO} / \mathrm{Li}_{2} \mathrm{SiO}_{3} @ \mathrm{C}$ composites was also investigated. At the current density of 100, 200, 500, 1000 and $2000 \mathrm{~mA} \mathrm{~g}^{-1}$, the delivered capacities at the corresponding $10^{\text {th }}$ cycle are $748.59,609.68$, 487.13, 311.52 and $197.80 \mathrm{~mA} \mathrm{~h} \mathrm{~g}^{-1}$, respectively. When the current density was switched to $200 \mathrm{~mA} \mathrm{~g}^{-1}$, the capacities restore to $601.10 \mathrm{~mA} \mathrm{~h} \mathrm{~g}{ }^{-1}$, which demonstrates a good rate capability of the $\mathrm{Si} / \mathrm{SiO} / \mathrm{Li}_{2} \mathrm{SiO}_{3} @ \mathrm{C}$ composites. When cycling at $100 \mathrm{~mA} \mathrm{~g}^{-1}$, the $2^{\text {nd }}$ discharge capacity is $731.51 \mathrm{~mA} \mathrm{~h} \mathrm{~g}^{-1}$ and at the $35^{\text {th }}$ cycle, this value is $573.99 \mathrm{~mA} \mathrm{~h} \mathrm{~g}^{-1}$, corresponding to $78.47 \%$ capacity retention (Fig. $5 \mathrm{~d}$ ).

Fig. 6 illustrates the impedance spectra of the pristine SiO, carbon-coated $\mathrm{SiO}$ and $\mathrm{Si} / \mathrm{SiO} / \mathrm{Li}_{2} \mathrm{SiO}_{3} @ \mathrm{C}$ anodes. All the spectra were well fitted by an equivalent circuit model shown in Fig. 6c$\mathrm{e}$, in which $R_{\mathrm{S}}\left(R_{1}\right)$ stands for the resistance of cell bulk including the electrolyte, electrode and separator. $R_{\mathrm{ct}}\left(R_{3} \& R_{4}\right)$ is the charge-transfer resistance and $W$ is the Warburg resistance. The $R_{\mathrm{s}}$ for the pristine $\mathrm{SiO}, \mathrm{SiO} @ \mathrm{C}$ and $\mathrm{Si} / \mathrm{SiO} / \mathrm{Li}_{2} \mathrm{SiO}_{3} @ \mathrm{C}$ composites are 1.6, 1.5, $1.7 \Omega$ and the $R_{\mathrm{ct}}\left(R_{3} \& R_{4}\right)$ are 113.5, 6.6, 17.2 $\Omega$, respectively. These results demonstrate that improved conductivity and kinetics are achieved through the introduction of surface carbon coating when compared with pristine SiO. ${ }^{44}$ However, due to the insulating nature of $\mathrm{Li}_{2} \mathrm{SiO}_{3}$ which distribute around the active $\mathrm{Si}$ and SiO domains, the $R_{\mathrm{ct}}$ for the $\mathrm{Si} / \mathrm{SiO} / \mathrm{Li}_{2} \mathrm{SiO}_{3} @ \mathrm{C}$ composites slightly increased by around $10 \Omega$ when compared with that of SiO@C. This disadvantage, on the other hand, is compensated by the improvement of the structural stability. Thus, the improvement in these aspects as well as the hierarchical design contributes to the high performance of the $\mathrm{Si} / \mathrm{SiO} / \mathrm{Li}_{2} \mathrm{SiO}_{3} @ \mathrm{C}$ composites. It is also noted that for $\mathrm{SiO} @ \mathrm{C}$ and $\mathrm{Si} / \mathrm{SiO} / \mathrm{Li}_{2} \mathrm{SiO}_{3} @ \mathrm{C}$ composites, $R_{3} / / \mathrm{CPE} 2$ both appear. The carbon coating (and possibly $\mathrm{Li}_{2} \mathrm{SiO}_{3}$ in the $\mathrm{Si} / \mathrm{SiO} /$ $\mathrm{Li}_{2} \mathrm{SiO}_{3}$ ) may be responsible for this as it generates another interface between the carbon layers and the active materials of $\mathrm{SiO}$ or $\mathrm{Si} / \mathrm{SiO} / \mathrm{Li}_{2} \mathrm{SiO}_{3}$. To further elucidate these phenomena, coin cells of the three different anode materials were charged and discharged at $50 \mu \mathrm{A}$. Under such small current, the polarizations, especially kinetic aspects, which occurred during the charge and discharge processes in the coin-cells, can be minimized. From Fig. S3, $\dagger$ we can observe that when comparing the 

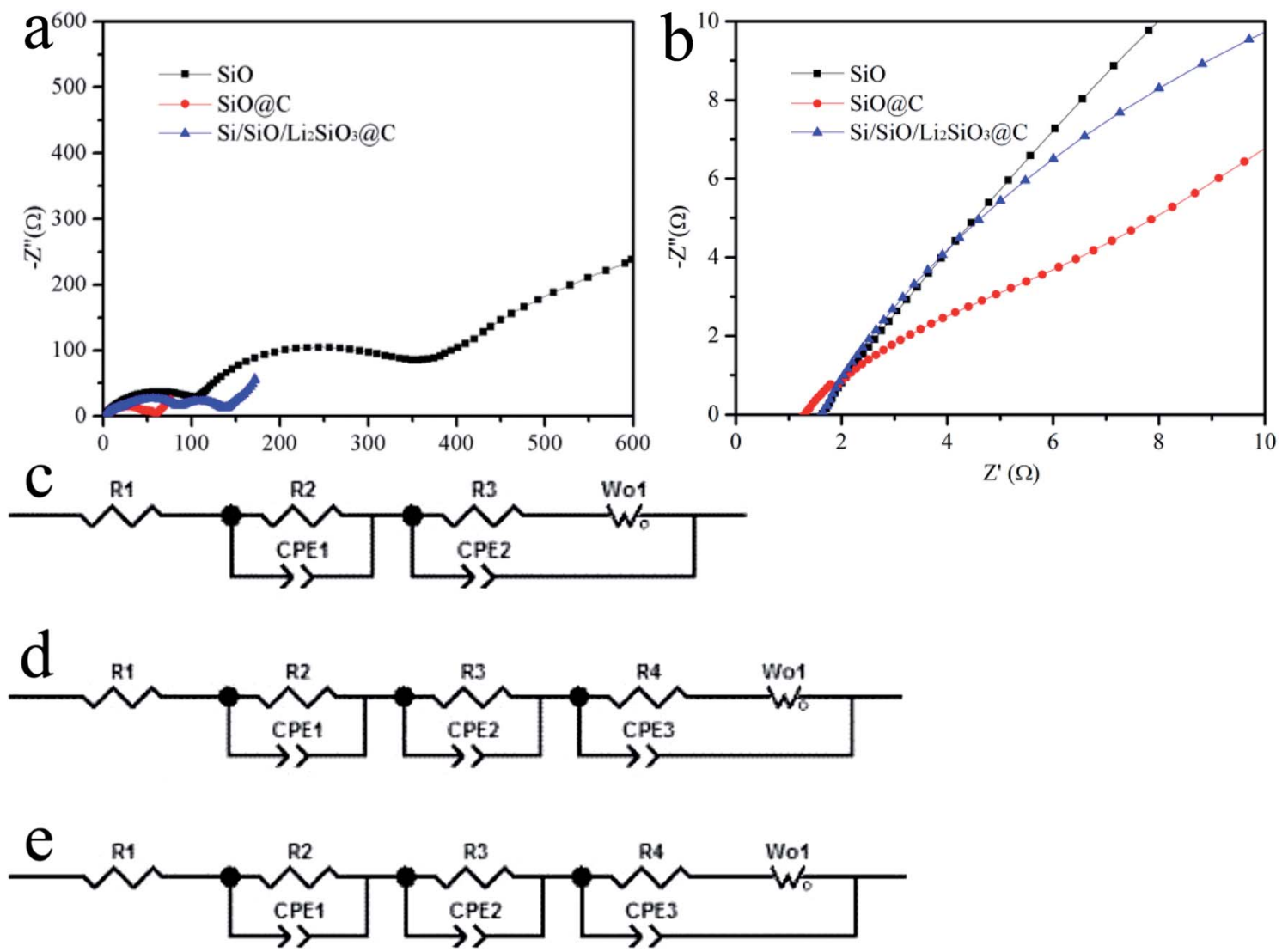

Fig. 6 (a and b) Electrochemical impedance spectra of the $\mathrm{SiO}$, $\mathrm{SiO}\left(\mathrm{C}\right.$ and $\mathrm{Si} / \mathrm{SiO} / \mathrm{Li}_{2} \mathrm{SiO}_{3} \mathrm{aC}$, (c-e) are the equivalent circuits of the ElS spectra of $\mathrm{SiO}, \mathrm{SiO} \cap \mathrm{C}$ and $\mathrm{Si} / \mathrm{SiO}_{/} \mathrm{Li}_{2} \mathrm{SiO}_{3} \mathrm{aC}$.

discharge and charge profiles (specific capacities < $100 \mathrm{~mA} \mathrm{~h} \mathrm{~g}{ }^{-1}$ ), the discharge potential of pristine $\mathrm{SiO}$ is $0.3-$ $0.4 \mathrm{~V}$ higher than those of $\mathrm{SiO} @ \mathrm{C}$ and $\mathrm{Si} / \mathrm{SiO} / \mathrm{Li}_{2} \mathrm{SiO}_{3} @ \mathrm{C}$ composites, which delivers the largest resistance polarization. The SiO@C sample shows the lowest overpotential and at the beginning of the discharge, a typical voltage hysteresis can be observed, revealing a gradual activation of the SiO materials that is protected by the carbon coating layer. The charge and discharge curves of $\mathrm{Si} / \mathrm{SiO} / \mathrm{Li}_{2} \mathrm{SiO}_{3} @ \mathrm{C}$ composites fall within the other two samples which indicates the improved conductivity of electrons or increase of lithium ions transfer hindrance from carbon coating or introduction of lithium silicates which optimizes the ionic conductivity and enhance the resistance to volume expansion, leading to an overall cycle stability.

\section{Conclusions}

In summary, we have developed a facile method to construct the hierarchical $\mathrm{Si} / \mathrm{SiO} / \mathrm{Li}_{2} \mathrm{SiO}_{3} @ \mathrm{C}$ composites for advanced LIBs anodes. The as-prepared composites not only have a high $1^{\text {st }}$ C.E. of $69.05 \%$ but also show improved cycling stability. Benefited from the partial prelithiation of SiO and carbon coating, the $\mathrm{Si} / \mathrm{SiO} / \mathrm{Li}_{2} \mathrm{SiO}_{3} @ \mathrm{C}$ anode has a superior electrochemical performance, with a prolonged cycle performance of $78.46 \%$ capacity retention over 35 cycles at $100 \mathrm{~mA} \mathrm{~g}^{-1}$ and an excellent rate property of $197.8 \mathrm{~mA} \mathrm{~h} \mathrm{~g}{ }^{-1}$ at a high current density of $2000 \mathrm{~mA} \mathrm{~h}^{-1}$. Such a design not only mitigates the volume expansion issue but also facilitates electron transport and guarantees structural robustness which pave the way for fabricate durable Si-based anode materials for lithium storage.

\section{Conflicts of interest}

There are no conflicts to declare.

\section{Acknowledgements}

This work was financially supported by National Key R\&D Program of China (2016YFB0100306). The authors thanks to the technicians from the Gotion Validation Engineering institute for the support in the FESEM, XRD and electrochemical characterizations.

\section{References}

1 E. Boisselier and D. Astruc, Gold Nanoparticles in Nanomedicine: Preparations, Imaging, Diagnostics, Therapies and Toxicity, Chem. Soc. Rev., 2009, 38, 1759-1782.

2 J. B. Goodenough and Y. Kim, Challenges for Rechargeable Li Batteries, Chem. Mater., 2010, 22, 587-603.

3 M. N. Obrovac and V. L. Chevrier, Alloy Negative Electrodes for Li-ion Batteries, Chem. Rev., 2014, 114, 11444-11502. 
4 J. Cabana, L. Monconduit, D. Larcher and M. R. Palacín, Beyond Intercalation-Based Li-Ion Batteries: The State of the Art and Challenges of Electrode Materials Reacting Through Conversion Reactions, Adv. Mater., 2010, 22, E170-E192.

5 Z. Wang, L. Zhou and X. W. David Lou, Metal Oxide Hollow Nanostructures for Lithium-ion Batteries, Adv. Mater., 2012, 24, 1903-1911.

6 X. Su, Q. Wu, J. Li, X. Xiao, A. Lott, W. Lu, B. W. Sheldon and J. Wu, Silicon-Based Nanomaterials for Lithium-Ion Batteries: A Review, Adv. Energy Mater., 2014, 4, 1300882.

7 J. O. Besenhard, J. Yang and M. Winter, Will Advanced Lithium-Alloy Anodes Have a Chance in Lithium-Ion Batteries, J. Power Sources, 1997, 68, 87-90.

8 C. K. Chan, H. Peng, G. Liu, K. McIlwrath, X. F. Zhang, R. A. Huggins and Y. Cui, High-performance Lithium Battery Anodes using Silicon Nanowires, Nat. Nanotechnol., 2008, 3, 31-35.

9 S. Ohara, J. Suzuki, K. Sekine and T. Takamura, A Thin Film Silicon Anode for Li-Ion Batteries Having a Very Large Specific Capacity and Long Cycle Life, J. Power Sources, 2004, 136, 303-306.

10 R. A. Huggins, Lithium Alloy Negative Electrodes Formed from Convertible Oxides, Solid State Ionics, 1998, 113, 57-67.

11 N. Liu, Z. Lu, J. Zhao, M. T. McDowell, H. Lee, W. Zhao and Y. Cui, A Pomegranate-Inspired Nanoscale Design for LargeVolume-Change Lithium Battery Anodes, Nat. Nanotechnol., 2014, 9, 187-192.

12 M. Yoshio, H. Wang, K. Fukuda, T. Umeno, N. Dimov and Z. Ogumi, Carbon-Coated $\mathrm{Si}$ as a Lithium-Ion Battery Anode Material, J. Electrochem. Soc., 2002, 149, A1598-A1603.

13 X. Huang, J. Yang, S. Mao, J. Chang, P. B. Hallac, C. R. Fell, B. Metz, J. Jiang, P. T. Hurley and J. Chen, Controllable Synthesis of Hollow Si Anode for Long-Cycle-Life LithiumIon Batteries, Adv. Mater., 2014, 26, 4326-4332.

14 J. Liu, P. Kopold, P. A. van Aken, J. Maier and Y. Yu, Energy Storage Materials from Nature through Nanotechnology: A Sustainable Route from Reed Plants to a Silicon Anode for Lithium-Ion Batteries, Angew. Chem., Int. Ed., 2015, 54, 9632-9636.

15 M. N. Obrovac, L. Christensen, D. B. Le and J. R. Dahn, Alloy Design for Lithium-Ion Battery Anodes, J. Electrochem. Soc., 2007, 154, A849-A855.

16 T. Cetinkaya, M. Uysal and H. Akbulut, Highly Reversible Silicon/Carbon Nanofiber/Carbon Nanotube Nanocomposite Anodes for Lithium Ion Batteries, ECS Trans., 2014, 63, 23-29.

17 X. J. Li and W. F. Jiang, Enhanced Field Emission from a Nest Array of Multi-Walled Carbon Nanotubes Grown on a Silicon Nanoporous Pillar Array, Nanotechnology, 2007, 18, 065203.

18 H. Kim, T. Hwang, K. Kang, J. Pichler-Nagl, D. So, S. Park and H. Huh, Preparation of Silicon Nanoball Encapsulated with Graphene Shell by CVD and Electroless Plating Process, $J$. Ind. Eng. Chem., 2017, 50, 115-122.

19 J. Zhou, T. Qian, M. Wang, N. Xu, Q. Zhang, Q. Li and C. Yan, Core-Shell Coating Silicon Anode Interfaces with
Coordination Complex for Stable Lithium-Ion Batteries, ACS Appl. Mater. Interfaces, 2016, 8, 5358-5365.

20 B. Jiang, S. Zeng, H. Wang, D. Liu, J. Qian, Y. Cao, H. Yang and X. Ai, Dual Core-Shell Structured Si@SiO $\mathrm{SC}_{x}$ Nanocomposite Synthesized via a One-Step Pyrolysis Method as a Highly Stable Anode Material for Lithium-Ion Batteries, ACS Appl. Mater. Interfaces, 2016, 8, 31611-31616.

21 M. Thakur, R. B. Pernites, N. Nitta, M. Isaacson, S. L. Sinsabaugh, M. S. Wong and S. L. Biswal, Freestanding Macroporous Silicon and Pyrolyzed Polyacrylonitrile as a Composite Anode for Lithium Ion Batteries, Chem. Mater., 2012, 24, 2998-3003.

22 Q. Si, K. Hanai, T. Ichikawa, A. Hirano, N. Imanishi, Y. Takeda and O. Yamamoto, A High Performance Silicon/ Carbon Composite Anode with Carbon Nanofiber for Lithium-Ion Batteries, J. Power Sources, 2010, 195, 17201725.

23 S. Song, S. W. Kim, D. J. Lee, Y. Lee, K. M. Kim, C. Kim, J. Park, Y. M. Lee and K. Y. Cho, Flexible Binder-Free Metal Fibril Mat-Supported Silicon Anode for High-Performance Lithium-Ion Batteries, ACS Appl. Mater. Interfaces, 2014, 6, 11544-11549.

24 J. Suk, D. Y. Kim, D. W. Kim and Y. Kang, Electrodeposited 3D Porous Silicon/Copper Films with Excellent Stability and High Rate Performance for Lithium-Ion Batteries, $J$. Mater. Chem. A, 2014, 2, 2478-2481.

25 J. Su, J. Zhao, L. Li, C. Zhang, C. Chen, T. Huang and A. Yu, Three-Dimensional Porous $\mathrm{Si}$ and $\mathrm{SiO}_{2}$ with in situ Decorated Carbon Nanotubes as Anode Materials for Li-ion Batteries, ACS Appl. Mater. Interfaces, 2017, 9, 17807-17813. 26 N. Dimov, S. Kugino and M. Yoshio, Carbon-Coated Silicon as Anode Material for Lithium Ion Batteries: Advantages and Limitations, Electrochim. Acta, 2003, 48, 1579-1587.

27 S. J. Lee, H. J. Kim, T. H. Hwang, S. Choi, S. H. Park, E. Deniz, D. S. Jung and J. W. Choi, Delicate Structural Control of Si$\mathrm{SiO}_{x}$-C Composite via High-Speed Spray Pyrolysis for Li-Ion Battery Anodes, Nano Lett., 2017, 17, 1870-1876.

28 E. San Andrés, A. Del Prado, I. Mártil, G. G. Díaz, F. L. Martinez, D. Bravo and F. J. López, Rapid Thermal Annealing Effects on Plasma Deposited $\mathrm{SiO}_{x}: \mathrm{H}$ Films, Vacuum, 2002, 67, 531-536.

29 S. W. Hwang, J. K. Lee and W. Y. Yoon, Electrochemical Behavior of Carbon-Coated Silicon Monoxide Electrode with Chromium Coating in Rechargeable Lithium Cell, $J$. Power Sources, 2013, 244, 620-624.

30 C. M. Park, W. Choi, Y. Hwa, J. H. Kim, G. Jeong and H. J. Sohn, Characterizations and Electrochemical Behaviors of Disproportionated $\mathrm{SiO}$ and Its Composite for Rechargeable Li-ion Batteries, J. Mater. Chem., 2010, 20, 4854-4860.

31 J. H. Kim, C. M. Park, H. Kim, Y. J. Kim and H. J. Sohn, Electrochemical Behavior of SiO Anode for Li Secondary Batteries, J. Electroanal. Chem., 2011, 661, 245-249.

32 K. W. Kim, H. Park, J. G. Lee, J. Kim, Y. Kim, J. H. Ryu, J. J. Kim and S. M. Oh, Capacity Variation of CarbonCoated Silicon Monoxide Negative Electrode for LithiumIon Batteries, Electrochim. Acta, 2013, 103, 226-230. 
33 J. K. Lee, J. H. Lee, B. K. Kim and W. Y. Yoon, Electrochemical Characteristics of Diamond-Like Carbon/ Cr Double-Layer Coating on Silicon Monoxide-Graphite Composite Anode for Li-Ion Batteries, Electrochim. Acta, 2014, 127, 1-6.

34 J. L. Gomez-Ballesteros and P. B. Balbuena, Reduction of Electrolyte Components on a Coated Si Anode of LithiumIon Batteries, J. Phys. Chem. Lett., 2017, 8, 3404-3408.

35 J. Liang, X. Li, Z. Hou, W. Zhang, Y. Zhu and Y. Qian, A Deep Reduction and Partial Oxidation Strategy for Fabrication of Mesoporous Si Anode for Lithium Ion Batteries, ACS Nano, 2016, 10, 2295-2304.

36 D. T. Ngo, H. T. Le, X. M. Pham, C. N. Park and C. J. Park, Facile Synthesis of Si@SiC Composite as an Anode Material for Lithium-Ion Batteries, ACS Appl. Mater. Interfaces, 2017, 9, 32790-32800.

37 G. Jeong, Y. Kim, S. A. Krachkovskiy and C. K. Lee, A Nanostructured $\mathrm{SiAl}_{0.2} \mathrm{O}$ Anode Material for Lithium Batteries, Chem. Mater., 2010, 22, 5570-5579.

38 I. W. Seong, K. T. Kim and W. Y. Yoon, Electrochemical Behavior of a Lithium-pre-doped Carbon-Coated Silicon Monoxide Anode Cell, J. Power Sources, 2009, 189, 511-514.

39 Y. Liu, Z. Y. Wen, X. Y. Wang, A. Hirano, N. Imanishi and Y. Takeda, Electrochemical Behaviors of Si/C Composite
Synthesized from F-containing Precursors, J. Power Sources, 2009, 189, 733-737.

40 X. Feng, J. Yang, P. Gao, J. Wang and Y. Nuli, Facile Approach to an Advanced Nanoporous Silicon/Carbon Composite Anode Material for Lithium Ion Batteries, RSC Adv., 2012, 2, 5701-5706.

41 Z. H. Liu, Y. L. Zhao, R. H. He, W. Luo, J. S. Meng, Q. Yu, D. Y. Zhao, L. Zhou and L. Q. Mai, Yolk@Shell $\mathrm{SiO}_{x} / \mathrm{C}$ Microspheres with Semi-Graphitic Carbon Coating on the Exterior and Interior Surfaces for Durable Lithium Storage, Energy Storage Materials, 2018, DOI: 10.1016/ j.ensm.2018.10.011.

42 C. S. Shan, K. F. Wu, H. J. Yen, C. N. Villarrubia, T. Nakotte, X. J. Bo, M. Zhou, G. Wu and H. L. Wang, Graphene Oxides Used as a New "Dual Role" Binder for Stabilizing Silicon Nanoparticles in Lithium-Ion Battery, ACS Appl. Mater. Interfaces, 2018, 10, 15665-15672.

43 T. Tan, P. K. Lee and D. W. Yu, Probing the Reversibility of Silicon Monoxide Electrodes for Lithium-Ion Batteries, $J$. Electrochem. Soc., 2019, 166, A5210-A5214.

44 L. Y. Shen, Z. X. Wang and L. Q. Chen, Carbon-coated hierarchically porous silicon as anode material for lithium ion batteries, RSC Adv., 2014, 4, 15314-15318. 